\title{
Trends in the Biodiversity and Invasive Species Dynamics: Local Implications on Forest, Grassland and Ruderal Vegetation in Bratislava City, Slovakia, Central Europe
}

\author{
Alena Rendeková1, Zuzana Randáková ${ }^{1}$, Ján Miškovic ${ }^{1} \&$ Karol Mičieta ${ }^{1}$ \\ ${ }^{1}$ Department of Botany, Faculty of Natural Sciences, Comenius University in Bratislava, Slovakia \\ Correspondence: Alena Rendeková, Department of Botany, Faculty of Natural Sciences, Comenius University in \\ Bratislava, Révová 39,81102 Bratislava, Slovakia. E-mail: alenarendekova@gmail.com
}

Received: October 8, 2017

Accepted: October 25, $2017 \quad$ Online Published: November 27, 2017

doi:10.5539/enrr.v7n4p52

URL: https://doi.org/10.5539/enrr.v7n4p52

\begin{abstract}
Biological invasions represent one of the most serious global environmental threats. One of their negative aspects is a biodiversity loss in the natural ecosystems. Our study reports the results of the evaluation of changes in the proportion of invasive alien species and the results of the evaluation of the changes of the diversity in various types of forest, grassland and ruderal vegetation of Bratislava city over the time. In total, 26 invasive alien taxa were recorded in the vegetation of Bratislava. The majority of invasive taxa were recorded in both time periods. Five invasive species (Echinocystis lobata, Fallopia japonica, Helianthus tuberosus, Juncus tenuis, and Solidago canadensis) were recorded only in the more recent period. Most of the invasive species prefer ruderal habitats, and some of them also invade the forest vegetation (mainly the floodplain forests). In the dry grasslands of the class Festuco-Brometea, no invasive species were recorded in both periods. The statistical analysis revealed the increase of the average percentual number of invasive alien species in the majority of classes of the forest and ruderal vegetation of Bratislava over the time. In the majority of classes, where the proportion of invasive species increased, the Shannon-Wiener index of diversity of all species decreased significantly over the time. Our results contribute to the knowledge about biological invasions in cities.
\end{abstract}

Keywords: alien plant taxa, Devínska Kobyla National Nature Reserve, neophytes, Shannon-Wiener diversity index

\section{Introduction}

Biological invasions of alien species are acknowledged as one of the serious environmental dangers for the conservation of native species and habitats worldwide (Pimentel et al., 2001). Alien plant species can completely change the structure of native communities, alter the trophic levels, nutrient cycling, hydrology and fire regime in a native ecosystem, or cause allelopathic effects and allergic reactions (Mack et al., 2000; Pyšek \& Richardson, 2010; Filep et al., 2016; Young, Parker, Gilbert, Guerra, \& Nunn, 2017). One of the most negative aspects of the introduction and spread of alien species is a biodiversity loss in the ecosystems (Mack et al., 2000; Manchester $\&$ Bullock, 2000; Stohlgren et al., 2011).

However, not all ecosystems and habitats are equally invaded (Lonsdale, 1999; Pyšek et al., 2010; Medvecká, Jarolímek, Senko, \& Svitok, 2014). Among the places where the alien species can be found, cities and urban areas are the most invaded ones (Lonsdale, 1999; Chytrý, Pyšek, Tichý, Knollová, \& Danihelka, 2005; Walter, Ess, Englisch, \& Kiehn, 2005; Vilá, Pino, \& Font, 2007; Chytrý et al., 2008; Pyšek et al., 2010; Medvecká et al., 2014; Lososová, Chytrý, Danihelka, Tichý, \& Ricotta 2016). Therefore, it is indispensable to focus on the research of the alien species in cities. As the alien species are notably represented in the cities, we chose the area of the Bratislava city for our research. Among the various types of the vegetation of cities, the ruderal vegetation is the most represented type, and it also harbours the highest proportion of alien species (Chytrý et al., 2005; Walter et al., 2005; Vilá et al., 2007; Chytrý et al., 2008; Simonová \& Lososová, 2008; Medvecká, Jarolímek, \& Zaliberová, 2009; Pyšek et al., 2010; Medvecká et al., 2014).

However, other types of vegetation can also be found in cities. Among the natural and seminatural types of vegetation, the riparian and floodplain forests are ones of the most invaded by the alien species (Walter et al., 2005; Vilá et al., 2007; Medvecká et al., 2014), as they are characterized by natural disturbances (periodic 
flooding), and at the same time they are altered by human disturbances (e.g. water regime management, damming etc.). These disturbances create new ecotopes for the establishment of alien plant species (Richardson et al., 2007). Therefore, we focused on the evaluation of the proportion of alien invasive species in the various types of the ruderal vegetation, and also in the various types of the forest vegetation, including the floodplain forests.

The very important type of the vegetation in Bratislava is also the seminatural dry calcareous grassland vegetation growing in The Devínska Kobyla National Nature Reserve. These xerothermophilous grasslands formed after a deforestation and the occurrence of this vegetation on the locality is conditioned by the agricultural activity, mainly by the traditional management (pasturing, mowing, and burning) (Kaleta, 1965; Hajdúk, 1986; Feráková \& Kocianová, 1997). The dry calcareous grasslands are one of the most species-rich communities ever (Willems, 1983; Bobbink et al., 1987; Feráková \& Kocianová, 1997; Miškovic \& Dúbravcová, 2004) and they harbour a large number of endangered and rare species (Feráková \& Kocianová, 1997; Senko \& Miškovic, 2006; Hegedüšová \& Senko, 2011). Therefore, we focused also on this type of vegetation, and we wanted to found out whether this type of vegetation is also in danger of being affected by alien invasive species.

Moreover, the comparison of the proportion of the alien invasive species in ruderal, semi-natural (dry grasslands) and natural (forests) vegetation can lead to remarkable results. That is the reason why we chose these types of vegetation for our research.

It is also important to take into consideration the fact that not all of the alien species represent the same threats. Only a small fraction of introduced species can survive in new areas for a long time, start to spread rapidly at the expense of biodiversity of the native species and become invasive (Mack et al., 2000; Pyšek \& Tichý, 2001). Hence, it is important to differentiate which alien species are casual, naturalized or invasive (Richardson et al., 2000) because only the invasive species present an actual problem.

Many researchers focused their studies on the whole group of alien plants in cities and urban habitats (e.g. Aronson, Handel, La Puma, \& Clemants, 2015; Zisenis, 2015; Žabka, Durišová, \& Eliáš, 2015; Lososová et al., 2016), or they focused on biodiversity and invasive species in various other habitats (Gastauer, Messias \& Neto, 2012), but invasive species in towns have rarely been the object of special studies (Bomanowska, Rewicz, Wolski, \& Katarzyna, 2017). Our study is focused precisely on the invasive group of the alien species in cities.

As one of the most negative consequences of the spread of invasive species is a biodiversity loss (Mack et al., 2000; Manchester \& Bullock, 2000; Stohlgren et al., 2011), we also focused on the analysis of the diversity of various types of the vegetation of Bratislava.

In the last decades, habitat alteration and introductions of alien plants have resulted in changes in the European flora and vegetation and typical of these trends are an increasing proportion of neophytes [ $=$ alien species, which were introduced to nonindigenous areas in Modern times] (Pyšek \& Mandák, 1997; Chocholoušková \& Pyšek, 2003; Lososová \& Simonová, 2008; Gregor, Bönsel, Starke-Ottich, \& Zizka, 2012) and the decreasing proportion of native species (Chocholoušková \& Pyšek, 2003; Lososová \& Simonová, 2008) and biodiversity (Pyšek et al., 2004) accordingly over the time.

Introduction of alien species, including invasive species, might have also had accelerated in Bratislava as a result of an increasing anthropogenic influence, mainly the increase in the transport of goods and passengers and the intensive construction during the last decades. The traffic network and the construction sites can serve as the sources of the propagules of the alien species. The invasive alien species penetrate into the ruderal habitats and from the ruderal habitats also to the natural landscape. The increasing proportion of alien invasive species could result in a significant change in the floristic composition not only in the ruderal vegetation, but also in the natural vegetation, mainly vegetation of Bratislava's forests, where several aggressive invasive taxa (e.g. Acer negundo, Ailanthus altissima, Aster novi-belgii agg., Robinia pseudoacacia, and Solidago gigantea) have recently spread (Feráková \& Jarolímek, 2011). There might also be the changes in the species composition of dry grasslands because of changes in management, mainly abandonment of traditional management (pasturing, and mowing) during the mid-20th century (Kaleta, 1965; Feráková \& Kocianová, 1997; Miškovic \& Dúbravcová, 2004; Hegedüšová \& Senko, 2011).

It is crucial to pay attention to dynamics of the diversity and species composition over the time, especially to the dynamics of invasive alien species. The knowledge about the invasive species dynamics can help to minimalize their invasions in the future. Therefore, our study is focused on the changes in the diversity and species composition, especially the changes in the invasive species proportion. Analysis of the changes in the biodiversity and the invasive species proportion enables us to predict future trends in biological invasions in various types of vegetation. 
The aims of our study are: (1) to compare the average values of the percentual number of invasive alien species in various syntaxa of the ruderal, seminatural (dry grassland) and natural (forest) vegetation; (2) to analyze the changes in the percentual number of invasive species in the ruderal, grassland, and forest vegetation over the time; (3) to compare the average values of the Shannon-Wiener index of species diversity in various syntaxa of the ruderal, grassland and forest vegetation; (4) to analyze the changes in the Shannon-Wiener index of species diversity in the ruderal, grassland, and forest vegetation over the time.

\section{Material and Methods}

\subsection{Study Area}

Bratislava, the capital city of Slovakia, is located in the south-western part of the country, close to the centre of Europe, near the borders with Austria, Czech Republic, and Hungary. The coordinates of the centre of the city are N $48^{\circ} 08^{\prime} 30^{\prime \prime}$, E $17^{\circ} 06^{\prime} 30^{\prime \prime}$. The city area covers $368 \mathrm{~km}^{2}$. The altitude ranges from 126 to $514 \mathrm{~m}$ a.s.l. The orographic units Podunajská rovina Flatland, Borská nížina Lowland and Malé Karpaty Mts. interfere to the area of the city. The River Danube flows through the city area (Feráková \& Jarolímek, 2011).

The area of the Bratislava city is one of the warmest and driest regions of Slovakia. The climatic conditions range from moderate to warm continental character. The warmest and driest climate conditions prevail in city areas, which belong to the Podunajská rovina Flatland (a mean annual temperature is $10.3^{\circ} \mathrm{C}$ and mean annual precipitation is $573 \mathrm{~mm}$ ). The most humid and cold zone is situated in the Malé Karpaty Mts. (a mean annual temperature is $9.5^{\circ} \mathrm{C}$ and mean annual precipitation is $\left.661 \mathrm{~mm}\right)$. The average duration of sunshine in Bratislava is one of the longest in Slovakia $(50 \%=2,100 \mathrm{~h} /$ year) (Feráková \& Jarolímek, 2011).

Ten Natura 2000 Sites, 2 Ramsar Sites, 1 National Nature Reserve, 1 National Nature Monument, 8 Nature reserves, and 20 Protected Areas are located in the area of Bratislava (Feráková \& Jarolímek, 2011). The very interesting locality in the Bratislava is The Devínska Kobyla National Nature Reserve. It is located in the most southern part of Malé Karpaty Mts. and it is unique mainly because of its thermophilous forest- and grassland-steppe flora. Also one of the most remarkable palaeonthologic localities in Slovakia lies in the area of the Devínska Kobyla National Nature Reserve. The locality is the old sandpit Sandberg, where remnants of rocks of the Tertiary Sea can be found. The horizontally deposited layers of the sea with the estimated age at 14 to 16 million years can be contemplated there. Fossils of the sea fauna can be still found in Sandberg (Feráková \& Kocianová, 1997).

The potential natural vegetation of Bratislava consisted mainly of forests: Fagus forests, Carpathian Quercus-Carpinus forests, Pontic-Pannonian Quercus forests, and Fraxinus-Ulmus-Quercus and Salix-Populus floodplain forests. Now, the major part of the city area is covered by the buildings and roads and only about $30 \%$ of the original forest cover has remained in Bratislava, mainly the Fagus and Carpinus betulus forests and some small remnants of Quercus-Ulmus-Fraxinus and Salix-Populus forests. Two-thirds of the original forests have been cleared for agricultural, housing and associated developments (Feráková \& Jarolímek, 2011).

In ruderal habitats, natural soils are covered by anthropogenic ones. The natural soils occur only in the interior of the Male Karpaty Mts., where mainly the medium to deep Euric Cambisols and Skeletic Leptosols with a complex of Anthrosols can be found. In the smaller parts of the city situated near the water streams, Gleyic Fluvisols (locally Gleyisols) occur. In the calcareous rocks of the Devínska Kobyla Hill have developed Rendzic Leptosols or locally Lithic Leptosols (Feráková \& Jarolímek, 2011).

\subsection{The Relevé Data}

For the analyses, we used approximately 800 phytosociological relevés from the Bratislava city. We used the relevés of the ruderal vegetation of the phytosociological classes Polygono-Poetea annuae, Sisymbrietea, Artemisietea vulgaris and Epilobietea angustifolii, the relevés of the dry grassland vegetation of the phytosociological class Festuco-Brometea and the relevés of the forest vegetation of the phytosociological classes Carpino-Fagetea sylvaticae, Alno glutinosae-Populetea albae and Salicetalia purpureae.

The class Polygono-Poetea annuae comprises subcosmopolitan therophyte-rich dwarf-herb ruderal vegetation, which grow in trampled habitats, e.g. the edges of pavements, playgrounds, or parking lots. The class Sisymbrietea includes zoo-anthropogenic and modern anthropogenic vegetation of disturbed sites, growing in cool- and cold-temperate regions of Eurasia. The class Artemisietea vulgaris encompasses perennial subxerophilous ruderal vegetation, which occupies the temperate and submediterranean zones of Europe. The class Epilobietea angustifolii includes tall-herb seminatural and anthropogenic perennial vegetation, which grow in wet areas with high nitrogen content in the soil in the temperate and boreal zones of Eurasia (Mucina et al., 2016). 
The class Festuco-Brometea encompasses dry grassland and steppe vegetation growing mostly on the base- and colloidrich soils in the submediterranean, nemoral and hemiboreal zones of Europe. In Central, Southern and Western Europe, it is represented by extrazonal vegetation in relict habitats or as seminatural and secondary grasslands (mainly pastures) (Mucina et al., 2016). In Bratislava, vegetation of this class occurs mainly in the area of Devínska Kobyla National Nature Reserve and is represented by seminatural dry calcareous grasslands (Feráková \& Kocianová, 1997)

The class Carpino-Fagetea sylvaticae comprises mesic deciduous and mixed forests of temperate Europe, Anatolia, the Caucasus and Southern Siberia. Vegetation of this class in Bratislava includes mainly the vegetation of the Central European alliance Carpinion betuli, which is comprised of the oak-hornbeam forests growing on deep nutrient-rich soils of the cool-temperate Europe and the British Isles. The vegetation of the alliance Carpinion betuli is significantly represented type of the forest vegetation in Bratislava. Another type of vegetation belonging to class Carpino-Fagetea sylvaticae, which is widespread in Bratislava, is the basiphilous beech forest vegetation of the alliance Fagion sylvaticae. In smaller parts of the area of Bratislava, sycamore maple forests of the alliance Tilio-Acerion also occur (Mucina et al., 2016).

The class Alno glutinosae-Populetea albae is comprised of the azonal alluvial forests of the Eurosiberian and Mediterranean regions. Vegetation of this class in Bratislava includes mainly the vegetation of the alliance Fraxino-Quercion roboris, which unites elm-ash and oak riparian floodplain forests on nutrient-rich brown alluvial soils in the nemoral zone of Europe. The class Salicetea purpureae encompasses willow scrub and low open forests of riparian habitats in the temperate to arctic zones of Europe. In Bratislava, this class is represented mainly by the vegetation of the alliance Salicion albae, which includes willow and poplar low open forests of river alluvia of the nemoral zone of Europe and high altitudes of the Mediterranean (Mucina et al., 2016).

We used data from two different time periods. The old dataset consisted of the relevés from the years 1960-1982 and was compiled from relevés published by Jarolímek (1983) and relevés from the Slovak National Phytosociological Database (Hegedüšová, 2007; Šibík, 2012) which match study area, the period and the selected syntaxa.

The more recent dataset consisted of the relevés from the years 2005-2016, out of which the majority were made by the authors of the study (Miškovic \& Dúbravcová, 2003; 2004; Rendeková, Kerekeš, \& Miškovic, 2014; Rendeková, 2016a,b) and a few relevés which match study area, the period and the selected syntaxa were obtained from the Slovak National Phytosociological Database (Hegedüšová, 2007; Šibík, 2012).

The phytosociological research in both periods was performed according to the methods of the Zürich-Montpellier school (Braun-Blanquet, 1964). In the old period, the old Braun-Blanquet cover-abundance scale was used. In the more recent period, the modified Braun-Blanquet cover-abundance scale, extended by $2 \mathrm{~m}$, $2 \mathrm{a}$ and $2 \mathrm{~b}$ values (Barkman, Doin, \& Segal, 1964) was used. The area of the data collection in both periods concerns the same districts of the studied cities.

\subsection{Data Analysis}

All relevés were stored using the TURBOVEG database (Hennekens \& Schaminée, 2001) and edited in the JUICE 7.0 programme (Tichý, 2002). The relevés made by the authors of the study were classified into the syntaxa using hierarchical clustering in the programme SYN-TAX 2000 (Podani, 2001). Various linkage methods and distance measures were tried. A beta-flexible method $(\beta=-0.25)$ in combination with Wishart's index proved to be the most effective parameters and were used in most of the hierarchical clustering analyses. The assignment of the other relevés to syntaxa followed the original assignment made by authors of relevés (Jarolímek, 1983; Hegedüšová, 2007; Šibík, 2012).

Bryophytes and the taxa of vascular plants determined only to the genus level were excluded from the analysis, and the taxa which occurred in more than one layer were merged. As different cover-abundance scales have been used in the old and the more recent relevés, to make the data comparable, the values $2 \mathrm{~m}, 2 \mathrm{a}$, and $2 \mathrm{~b}$ in both datasets were converted to value 2 .

Alien taxa with invasive status in the relevés were identified according to the list of alien vascular plant species in the Slovak Republic (Medvecká et al., 2012) and the list of recorded invasive taxa was compiled. The Raunkiær's life forms and the residence status of recorded invasive alien taxa were also determined according to the list of alien vascular plant species in the Slovak Republic (Medvecká et al., 2012). The average percentual number of invasive species was calculated for each relevé, using the JUICE 7.0 programme.

The Shannon-Wiener index of diversity [H'] (Hill, 1973) was calculated for each of the old and the recent relevé of every class, using the JUICE 7.0 programme. 
Afterwards, the changes in the average values of the percentual number of invasive species and the average values of the Shannon-Wiener index of diversity between the old and the recent data of each class were compared using the MAIN EFFECTS ANOVA analysis in the STATISTICA 7.0 programme (Hill \& Lewicki, 2007). The STATISTICA 7.0 programme was used to create the figures (Figures 1-4) which demonstrate the results of the analysis.

\subsection{Nomenclature}

The nomenclature of the taxa follows Marhold (1998), the nomenclature of the syntaxa follows Mucina et al. (2016).

\section{Results}

\subsection{The Proportion of Invasive Species and Its Dynamics}

The analysis showed that the most invaded type of vegetation in Bratislava is the ruderal vegetation. Among the classes of the ruderal vegetation, the highest average percentual number of invasive alien species was recorded in the classes Sisymbrietea and Epilobietea angustifolii (Figure 1). The percentual number of invasive species in the class Sisymbrietea was $12.4 \%$ in the old period and $9.7 \%$ in the more recent period. In the class Epilobietea angustifolii it was $8.5 \%$ in the old period and $16.3 \%$ in the more recent period (Figure 1).

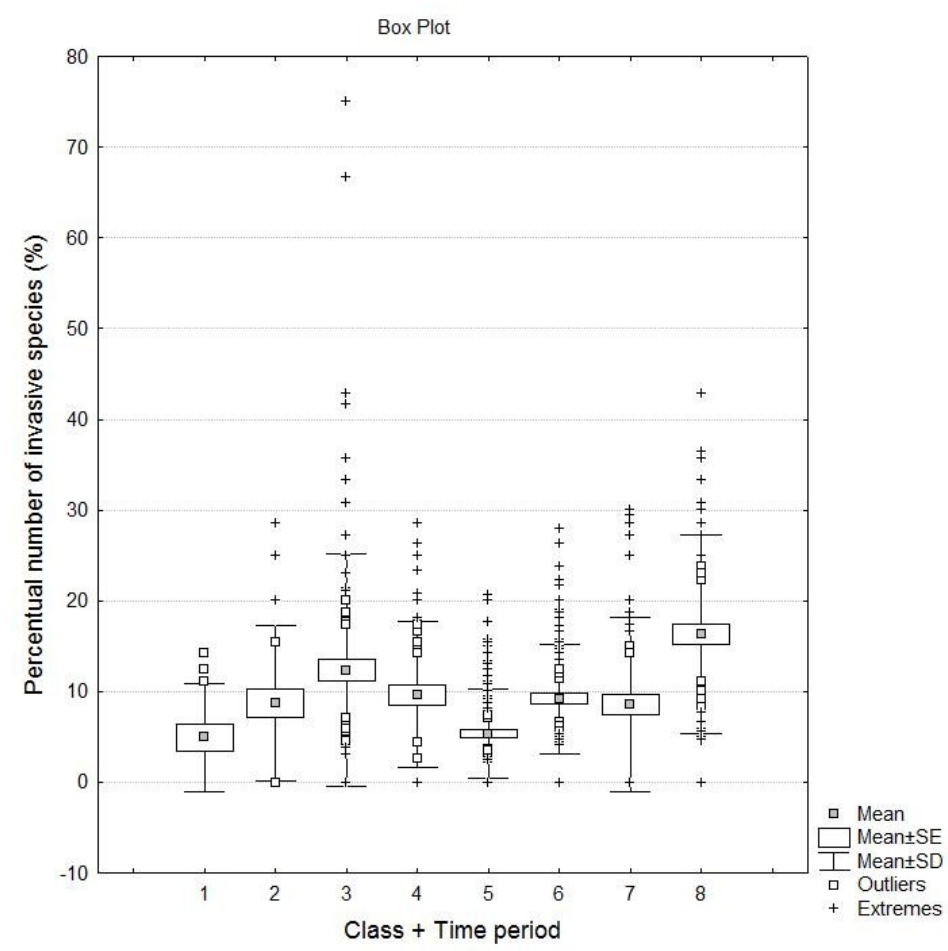

Figure 1. The comparison of the average percentual number of invasive taxa in the old and the more recent relevés of the ruderal vegetation of Bratislava city

Explanation:

1 - class Polygono-Poetea annuae, old phytosociological relevés (from the years 1960-1982);

2 - class Polygono-Poetea annuae, more recent phytosociological relevés (from the years 2005-2016);

3 - class Sisymbrietea, old phytosociological relevés (from the years 1960-1982);

4 - class Sisymbrietea, more recent phytosociological relevés (from the years 2005-2016);

5 - class Artemisietea vulgaris, old phytosociological relevés (from the years 1960-1982);

6 - class Artemisietea vulgaris, more recent phytosociological relevés (from the years 2005-2016);

7 - class Epilobietea angustifolii, old phytosociological relevés (from the years 1960-1982);

8 - class Epilobietea angustifolii, more recent phytosociological relevés (from the years 2005-2016). 
The second most invaded type of vegetation in Bratislava is the floodplain forest of the class Salicetea purpureae (Figure 2), where the percentual number of invasive species in the more recent period reached $8.9 \%$. In the more recent period, the relatively high average percentual number of the invasive species (7.1\%) was also recorded in the vegetation of the floodplain forests of the class Alno glutinosae-Populetea albae (Figure 2). The deciduous and mixed forests of the class Carpino-Fagetea sylvaticae were less affected by the presence of invasive species (Figure 2), the percentual number of invasive species in this class was only $3.5 \%$ in both periods (Figure 2 ).

In the seminatural dry calcareous grassland vegetation of the class Festuco-Brometea in Devínska Kobyla National Nature Reserve, no invasive species were recorded in the old period nor in the more recent period (Figure 2, Table 1). Therefore, the percentual number of invasive species in the vegetation of this class in both periods was zero. Some invasive species have been found in the territory of Devínska Kobyla National Nature Reserve, but the invasive species form dense stands in the invaded parts of the area, and the xerothermophilous grassland vegetation can not grow there. Therefore, directly in the stands of the dry grasslands, no invasive species were recorded.

The statistically significant results of the analysis of the changes in the average percentual number of invasive species over the time showed the increase of the percentual number of invasive species in the majority of the classes of the ruderal vegetation (Figure 1) and also in the majority of classes of the natural vegetation (Figure 2).

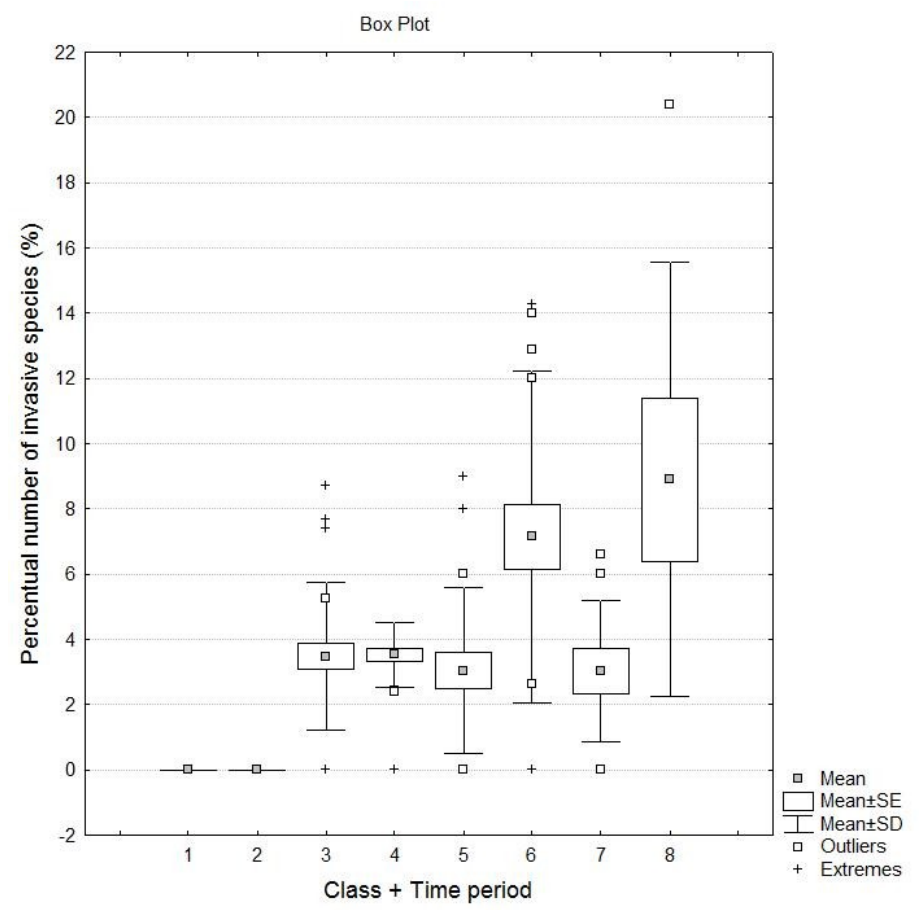

Figure 2. The comparison of the average percentual number of invasive taxa in the old and the more recent relevés of the grassland and forest vegetation of Bratislava city

\section{Explanation:}

1 - class Festuco-Brometea, old phytosociological relevés (from the years 1960-1982);

2 - class Festuco-Brometea, more recent phytosociological relevés (from the years 2005-2016);

3 - class Carpino-Fagetea sylvaticae, old phytosociological relevés (from the years 1960-1982);

4 - class Carpino-Fagetea sylvaticae, more recent phytosociological relevés (from the years 2005-2016);

5 - class Alno glutinosae-Populetea albae, old phytosociological relevés (from the years 1960-1982);

6 - class Alno glutinosae-Populetea albae, more recent phytosociological relevés (from the years 2005-2016);

7 - class Salicetalia purpureae, old phytosociological relevés (from the years 1960-1982);

8 - class Salicetalia purpureae, more recent phytosociological relevés (from the years 2005-2016) 
The most significant increase in the percentual number of invasive taxa was recorded in the ruderal vegetation of the class Epilobietea angustifolii $[\mathrm{F}(1,163)=22.7, \mathrm{p}<0.001]$, where it has risen from $8.5 \%$ to $16.3 \%$. A significant increase from 5.3\% to $9.2 \%$ was also recorded in the class Artemisietea vulgaris $[\mathrm{F}(1,277)=34.1, \mathrm{p}$ $<0.001]$ (Figure 1). The percentual number of invasive taxa also increased in the class Polygono-Poetea annuae, but these change proved to be statistically not significant. The percentual number of invasive species decreased only in the class Sisymbrietea, but these change also proved to be statistically not significant $(\mathrm{p}>0.05)$.

The significant increase in the percentual number of invasive taxa was recorded not only in the ruderal vegetation but also in the forest vegetation of the class Alno glutinosae-Populetea albae $[\mathrm{F}(1,45)=11.3, \mathrm{p}=$ $0.002]$, where it has risen from $3.0 \%$ to $7.1 \%$ and in the class Salicetea purpurae $[\mathrm{F}(1,15=6.9, \mathrm{p}=0.190]$ (Figure 2), where it increased from $3.0 \%$ to $8.9 \%$. The percentual number of invasive species in the vegetation of the class Carpino-Fagetea sylvaticae remained unchanged [the difference in the values between the old and the more recent period proved to be statistically not significant $(p>0.05)$ ] (Figure 2).

In total, 26 invasive alien taxa were found in the vegetation of Bratislava (Table 1). Most of them were recorded in both periods. Five invasive species (Echinocystis lobata, Fallopia japonica, Helianthus tuberosus, Juncus tenuis, and Solidago canadensis) were recorded only in the more recent period (Table 1).

All 26 invasive taxa were present in the ruderal vegetation. In the forest vegetation, 19 invasive taxa were recorded. In the grassland vegetation, no invasive taxa were recorded (Table 1). Most of the recorded invasive species were present only in some classes of the vegetation of Bratislava. Only the species Negundo aceroides and Stenactis annua were recorded in almost all types of vegetation (Table 1).

The most frequently occurring invasive alien species in the therophyte-rich trampled ruderal vegetation of the class Polygono-Poetea annuae were Ambrosia artemisiifolia and Matricaria discoidea. In the anthropogenic vegetation of the therophytes of disturbed sites of the class Sisymbrietea, the invasive species Amaranthus retroflexus, Ambrosia artemisiifolia, Atriplex tatrica, Conyza canadensis, Echinochloa crus-galli, Galinsoga parviflora, G. urticifolia, and juvenile forms of invasive trees Ailanthus altissima and Negundo aceroides were present frequently. The most frequently occurring invasive species in the perennial subxerophilous ruderal vegetation of the class Artemisietea vulgaris was Stenactis annua. The vegetation of this class also harbours invasive species such as Ambrosia artemisiifolia, Cardaria draba, Solidago canadensis, and S. gigantea. Many invasive taxa prefer the vegetation of the class Epilobietea angustifolii. In the more recent period, whole stands and communities of this class formed by invasive neophytes such as Aster novi-belgii agg., Fallopia japonica, Helianthus tuberosus, Impatiens glandulifera, Solidago canadensis, and S. gigantea have been recorded (Table 1).

The most frequently recorded invasive species in the deciduous and mixed forests of the class Carpino-Fagetea sylvaticae were Impatiens parviflora and Robinia pseudoacacia. In the hardwood floodplain forests of the class Alno glutinosae-Populetea albae, the invasive herbs Aster novi-belgii agg., Impatiens parviflora, Solidago gigantea and invasive trees Ailanthus altissima, Negundo aceroides, and Robinia pseudoacacia occur frequently. In the softwood floodplain forests of the class Salicetalia purpureae, the most freqently recorded invasive herbs were Aster novi-belgii agg., Bidens frondosa, Impatiens glandulifera, I. parviflora, Solidago canadensis, S. gigantea and the most frequently recorded invasive trees were Ailanthus altissima, Negundo aceroides, and Robinia pseudoacacia. In the comparison to the hardwood floodplain forests, the vegetation of the softwood forests also comprises the invasive species Echinochloa crus-galli, Echinocystis lobata, Fallopia japonica, and Helianthus tuberosus (Table 1).

In the vegetation of the dry grasslands in Devínska Kobyla National Nature Reserve, no invasive species were recorded, but some of the invasive species occur in the area of Devínska Kobyla. For example, in some parts of the area, the invasive tree Robinia pseudoacacia is quite widespread. However, it forms dense stands in the invaded parts of the area, making it impossible for the dry grassland vegetation to grow there. 
Table 1. List of the recorded invasive taxa and their occurrence in various classes of the ruderal, grassland and forest vegetation of Bratislava and in the time periods

\begin{tabular}{|c|c|c|c|c|c|c|c|c|c|c|c|}
\hline \multirow{3}{*}{ Taxon } & \multirow{3}{*}{$\begin{array}{l}\text { Life } \\
\text { form }\end{array}$} & \multirow{3}{*}{$\begin{array}{l}\text { Residence } \\
\text { time }\end{array}$} & \multicolumn{9}{|c|}{ Occurrence in the relevés of Bratislava } \\
\hline & & & \multicolumn{4}{|c|}{$\begin{array}{c}\text { Ruderal } \\
\text { vegetation }\end{array}$} & \multirow{2}{*}{$\begin{array}{c}\begin{array}{c}\text { Grassland } \\
\text { vegetation }\end{array} \\
\text { Festuco-Brometea }\end{array}$} & \multicolumn{3}{|c|}{ Forest vegetation } & \multirow[t]{2}{*}{$\begin{array}{c}\text { Total (all types } \\
\text { of vegetation) }\end{array}$} \\
\hline & & & $P-P$ & $S$ & $A V$ & $E A$ & & $\begin{array}{c}\text { Car.-Fag. } \\
\text { syl. }\end{array}$ & $\begin{array}{c}\text { Alno-Pop. } \\
\text { al. }\end{array}$ & $\begin{array}{l}\text { Sal. } \\
\text { pur. }\end{array}$ & \\
\hline Ailanthus altissima & $\mathrm{Ph}$ & neo & - & $\mathrm{r}$ & $\mathrm{b}$ & $\mathrm{b}$ & - & - & $\mathrm{r}$ & $\mathrm{r}$ & $\mathrm{b}$ \\
\hline Amaranthus retroflexus & $\mathrm{T}$ & neo & - & $\mathrm{b}$ & o & - & - & - & - & - & $\mathrm{b}$ \\
\hline Ambrosia artemisiifolia & $\mathrm{T}$ & neo & $\mathrm{r}$ & $\mathrm{b}$ & $\mathrm{b}$ & $b$ & - & - & - & - & $\mathrm{b}$ \\
\hline Apera spica-venti & $\mathrm{T}$ & $\operatorname{arch}$ & - & $\mathrm{b}$ & $\mathrm{b}$ & - & - & - & - & - & $\mathrm{b}$ \\
\hline Aster novi-belgii agg. & $\mathrm{He}$ & neo & - & $\mathrm{r}$ & $\mathrm{b}$ & $\mathrm{b}$ & - & $\mathrm{r}$ & $\mathrm{r}$ & $\mathrm{r}$ & $\mathrm{b}$ \\
\hline Atriplex tatarica & $\mathrm{T}$ & $\operatorname{arch}$ & $\mathrm{b}$ & $\mathrm{b}$ & $\mathrm{b}$ & o & - & - & - & - & $\mathrm{b}$ \\
\hline Bidens frondosa & $\mathrm{T}$ & neo & - & - & o & $\mathrm{r}$ & - & $b$ & $\mathrm{r}$ & $\mathrm{r}$ & $\mathrm{b}$ \\
\hline Cardaria draba & $\mathrm{He}$ & $\operatorname{arch}$ & $\mathrm{r}$ & $\mathrm{b}$ & $\mathrm{b}$ & $\mathrm{b}$ & - & - & - & - & $\mathrm{b}$ \\
\hline Conyza canadensis & $\mathrm{T}$ & neo & $\mathrm{r}$ & $\mathrm{b}$ & $\mathrm{b}$ & $\mathrm{b}$ & - & - & - & - & $\mathrm{b}$ \\
\hline Echinochloa crus-galli & $\mathrm{T}$ & $\operatorname{arch}$ & $\mathrm{r}$ & $\mathrm{b}$ & $\mathrm{b}$ & $\mathrm{r}$ & - & - & - & $\mathrm{r}$ & $\mathrm{b}$ \\
\hline Echinocystis lobata & $\mathrm{T}$ & neo & - & - & - & $\mathrm{r}$ & - & - & - & $\mathrm{r}$ & $\mathrm{r}$ \\
\hline Fallopia japonica & G & neo & - & - & - & $\mathrm{r}$ & - & - & - & $\mathrm{r}$ & $\mathrm{r}$ \\
\hline Galinsoga parviflora & $\mathrm{T}$ & neo & - & o & - & o & - & $\mathrm{b}$ & $\mathrm{b}$ & $\mathrm{b}$ & o \\
\hline Galinsoga urticifolia & $\mathrm{T}$ & neo & - & $\mathrm{r}$ & - & $\mathrm{b}$ & - & $\mathrm{r}$ & - & $\mathrm{r}$ & $\mathrm{b}$ \\
\hline Helianthus tuberosus & $\mathrm{He}$ & neo & - & $\mathrm{r}$ & $\mathrm{r}$ & $\mathrm{r}$ & - & - & - & $\mathrm{r}$ & $\mathrm{r}$ \\
\hline Impatiens glandulifera & $\mathrm{T}$ & neo & - & - & - & $b$ & - & - & $\mathrm{r}$ & $\mathrm{b}$ & $\mathrm{b}$ \\
\hline Impatiens parviflora & $\mathrm{T}$ & neo & - & $\mathrm{r}$ & $\mathrm{b}$ & $\mathrm{b}$ & - & $\mathrm{b}$ & $\mathrm{r}$ & $\mathrm{b}$ & $\mathrm{b}$ \\
\hline Juncus tenuis & $\mathrm{He}$ & neo & $\mathrm{r}$ & - & - & - & - & $\mathrm{r}$ & - & - & $\mathrm{r}$ \\
\hline Lycium barbarum & $\mathrm{Ph}$ & neo & - & - & - & $\mathrm{b}$ & - & $\mathrm{r}$ & $\mathrm{r}$ & $\mathrm{b}$ & $\mathrm{b}$ \\
\hline Matricaria discoidea & $\mathrm{T}$ & neo & $\mathrm{b}$ & $\mathrm{b}$ & o & - & - & - & - & - & $\mathrm{b}$ \\
\hline Negundo aceroides & $\mathrm{Ph}$ & neo & $\mathrm{r}$ & $\mathrm{b}$ & $\mathrm{r}$ & $\mathrm{r}$ & - & $\mathrm{r}$ & $\mathrm{r}$ & $\mathrm{r}$ & $\mathrm{b}$ \\
\hline Robinia pseudoacacia & $\mathrm{Ph}$ & neo & - & $\mathrm{b}$ & $\mathrm{b}$ & $\mathrm{b}$ & - & $\mathrm{b}$ & $\mathrm{b}$ & $\mathrm{b}$ & $\mathrm{b}$ \\
\hline Rumex patientia & $\mathrm{He}$ & neo & - & $\mathrm{b}$ & $\mathrm{b}$ & $\mathrm{b}$ & - & $\mathrm{b}$ & $\mathrm{b}$ & $\mathrm{b}$ & $\mathrm{b}$ \\
\hline Solidago canadensis & $\mathrm{He}$ & neo & - & $\mathrm{r}$ & $\mathrm{r}$ & $\mathrm{r}$ & - & $\mathrm{r}$ & $\mathrm{r}$ & $\mathrm{r}$ & $\mathrm{r}$ \\
\hline Solidago gigantea & $\mathrm{He}$ & neo & - & $\mathrm{b}$ & $\mathrm{b}$ & $\mathrm{b}$ & - & $\mathrm{r}$ & $\mathrm{r}$ & $\mathrm{b}$ & $\mathrm{b}$ \\
\hline Stenactis anпиа & $\mathrm{T}$ & neo & $\mathrm{r}$ & $\mathrm{b}$ & $\mathrm{b}$ & $\mathrm{b}$ & - & $\mathrm{r}$ & $\mathrm{r}$ & $\mathrm{r}$ & $\mathrm{b}$ \\
\hline
\end{tabular}

Explanation:

$P$-P - class Polygono-Poetea annuae,

$S$ - class Sisymbrietea,

$A V$ - class Artemisietea vulgaris,

EA - class Epilobietea angustifolii,

Car.-Fag. syl. - class Carpino-Fagetea sylvaticae,

Alno-Pop. al. - class Alno glutinosae-Populetea albae,

Sal. pur. - class Salicetalia purpureae;

$\mathrm{G}$ - geophyte,

$\mathrm{He}$ - hemocryptophyte,

$\mathrm{Ph}$ - phanerophyte,

$\mathrm{T}$ - therophyte;

arch - archaeophyte (= alien plant taxon introduced to nonindigenous area before the end of the Middle Ages),

neo - neophyte ( = alien plant taxon introduced to nonindigenous area in Modern times);

o - taxon was recorded only in the old phytosociological relevés (from the years 1960-1982),

$\mathrm{r}$ - taxon was recorded only in the more recent phytosociological relevés (from the years 2005-2016),

$\mathrm{b}-$ taxon was recorded in both time periods,

- - taxon was not recorded 


\subsection{The Biodiversity and Its Dynamics}

The comparison of various vegetation types of Bratislava regarding the biodiversity (Figures 3 and 4) showed that Shannon-Wiener diversity index reaches the highest average values (more than 3.0) in the dry grassland vegetation of the class Festuco-Brometea (Figure 4). Relatively high average values of the diversity index (approximately 2.3) were also recorded in almost all classes of the forest vegetation (Figure 4). Among the classes of the ruderal vegetation, the highest biodiversity was recorded in the class Artemisietea vulgaris, mainly in the old period (the average values of the diversity index were approximately 2.1 ), followed by the class Sysimbrietea with average values of the diversity index approximately 1.7 (Figure 3). The class Polygono-Poetea annuae was the class with the lowest biodiversity (approximately 1.0), and the average values of the index of diversity were low (approximately 1.4) also in the class Epilobietea angustifolii (Figure 3).

The comparison of the average values of the Shannon-Wiener diversity index between the old and the more recent periods is also presented in the Figures 3 and 4, where we can see that in the majority of the classes of vegetation in Bratislava, the diversity index decreased over the time.

The significant decrease of the diversity index was recorded in the ruderal vegetation of the classes Artemisietea vulgaris $[\mathrm{F}(1,277)=36.6, \mathrm{p}<0.001]$ and Epilobietea angustifolii $[\mathrm{F}(1,163)=4.4, \mathrm{p}=0.038]$ (Figure 3 ) and in the floodplain forest vegetation of the class Salicetea purpureae $[\mathrm{F}(1,15)=7.0, \mathrm{p}=0.019)]$ (Figure 4). In the class Salicetea purpureae, the difference in the average values of the diversity index between the old and the more recent period is really remarkable, because the values decreased from 2.38 to 1.76 (Figure 4). In the majority of the other classes (e.g. Alno glutinosae-Populetea albae and Festuco-Brometea), only the slight decrease of the diversity index was recorded (Figure 4), or there was not a change (classes Carpino-Fagetea sylvaticae and Polygono-Poetea annuae) between the old and the more recent period [the difference proved to be statistically not significant ( $p>0.05)$ ] (Figures 3 and 4).

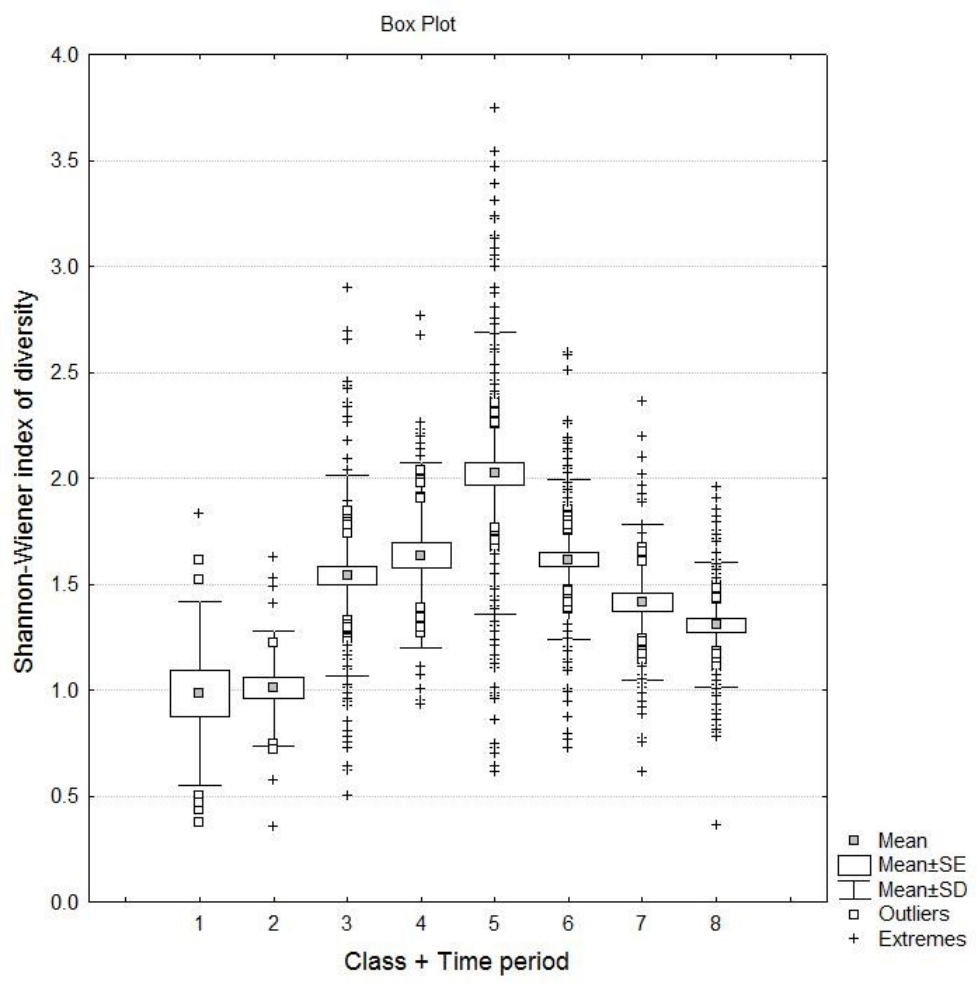

Figure 3. The comparison of the Shannon-Wiener index of diversity $\left[\mathrm{H}^{\prime}\right]$ in the old and the more recent relevés of the ruderal vegetation of Bratislava city

Explanation corresponds to those in Figure 1. 


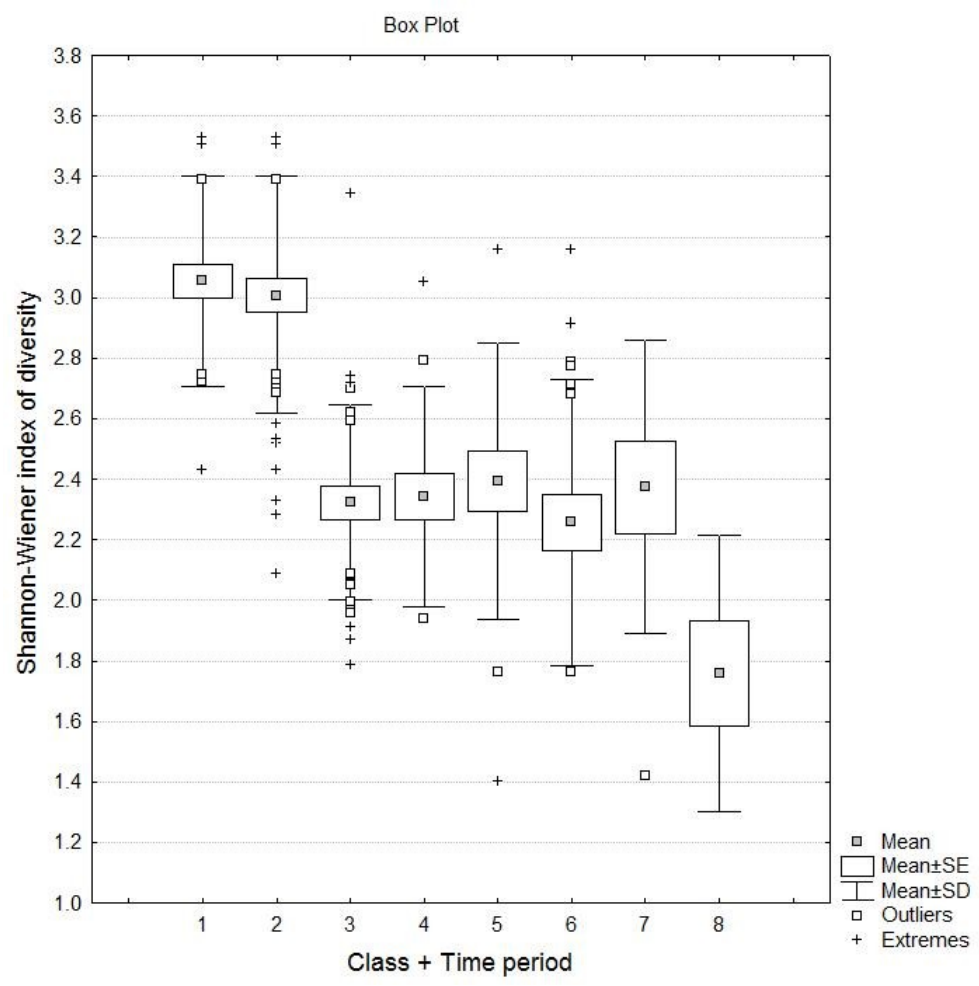

Figure 4. The comparison of the Shannon-Wiener index of diversity $\left[\mathrm{H}^{\prime}\right]$ in the old and the more recent relevés of the grassland and forest vegetation of Bratislava city

Explanation corresponds to those in Figure 2.

\section{Discussion}

The ruderal plant communities were the richest in alien invasive species among all of the analyzed types of vegetation of Bratislava city (Figures 1 and 2). There can be several explanations for the fact that many invasive species can be found in the ruderal vegetation and the classes of seminatural and natural vegetation are less invaded (Figures 1 and 2). One of the explanations can be that the ruderal plant communities were recorded right beside the traffic network and on places such as construction sites, which serve as the sources of the propagules of the alien invasive species. Therefore, the high proportion of the invasive species in the ruderal communities can be expected.

Among the ruderal types of vegetation, the class Epilobietea angustifolii was one of the classes where the highest proportion of the invasive species was recorded, mainly in the more recent period (Figure 1). Many of the recently recorded communities of this class were stands of perennial tall herbs formed monodominantly by the invasive taxa (e.g. by Aster novi-belgii agg., Fallopia japonica, Helianthus tuberosus, Solidago canadensis, $S$. gigantea) lining ruderalized watercourses (Rendeková, 2016a), which could cause the high percentual number of invasive species in the vegetation of this class overall.

Further, the resistance of the community to plant invasion correlates with the effect of disturbance, which creates empty niches and increases the probability of colonizing the community by alien species (Hobbs \& Huenneke, 1992; Mack et al., 2000; Walter et al., 2005). Many ruderal habitats experience strong disturbances. For example, the vegetation of the class Sisymbrietea, which was also one of the most invaded classes among ruderal types of vegetation (Figure 1), frequently occurs on the construction sites and other extremely disturbed places. The similar tendency can also be seen in the studies from Czech Republic (Chytrý et al., 2005; Chytrý et al., 2008; Simonová \& Lososová, 2008) in the case of the proportion of alien taxa. These studies confirm that habitat types with a high level of disturbance contain many alien taxa. According to these studies, the disturbance regime is the main difference between the most invaded and other habitats. For ruderal habitats, the impact of disturbance was found to be the most significant determinant of invasion (Chytrý et al., 2005; Chytrý et al., 2008; Simonová \& Lososová, 2008). 
The effect of disturbance could play a role in the invasion not only in the man-made habitats but also in the natural types of vegetation, because the high proportion of invasive species was also recorded in the floodplain forests (Figure 2), where natural disturbances (periodic flooding) and also human disturbances (e.g. water regime management, damming etc.) occur. The flooding causes not only disturbances but also brings a supply of nutrients. According to several studies (Chytrý et al., 2008; Walter et al., 2005), the amount of nutrients is also one of the main factors affecting the invasibility of the community. Moreover, floodplain forests are located along rivers which are important corridors for spreading of alien species (Richardson et al., 2007; A. Zajac, Tokarska-Guzik, \& M. Zajac, 2011; Petrášová, Jarolímek, \& Medvecká, 2013).

The deciduous and mixed forest vegetation of the class Carpino-Fagetea sylvaticae, where lower values of the percentual number of the invasive species were recorded (Figure 2) and the grassland vegetation of the class Festuco-Brometea, where no invasive species were recorded, grow in a greater distance from the sources of the propagules of alien species and on the not so extremely disturbed habitats compared to ruderal habitats. There occur the disturbances on the habitats of the class Festuco-Brometea (e.g. mowing and pasturing), but the level of disturbance is lower than in the ruderal bahitats. These facts can explain the low proportion of the invasive species in these types of vegetation. In the case of the dry grasslands of the class Festuco-Brometea, the factor which limits the invasion of alien plants might also be the amount of the nutrients, as these plant communities grow on nutrient-poor sites.

Therefore, we can state that our results indirectly support the findings of other authors (Hobbs \& Huenneke, 1992; Mack et al., 2000; Chytrý et al., 2005; Walter et al., 2005; Chytrý et al., 2008; Simonová \& Lososová, 2008; Catford et al., 2011), suggesting that some of the main factors causing the high degree of invasion in plant communities are a high level of disturbance and a high nutrient supply.

The results of our study are similar to the findings of other authors (Chytrý et al., 2005; Walter et al., 2005; Chytrý et al., 2008; Simonová \& Lososová, 2008; Medvecká et al., 2009; Petrášová et al. 2013; Medvecká et al., 2014), which proved that the proportion of alien species is very high in the anthropogenic vegetation of annuals of the class Sisymbrietea, and is also high in the vegetation of tall perennial herbs along watercourses from the class Epilobietea angustifolii and floodplain forests (classes Alno glutinosae-Populetea albae and Salicetalia purpureae). The deciduous and mixed forests from the class Carpino-Fagetea sylvaticae and the grasslands from the class Festuco-Brometea are invaded to a lesser degree (Medvecká et al., 2014).

The majority of the recorded invasive taxa were bounded only to some classes of the vegetation of Bratislava. Only a few species were present in almost all of the classes (Table 1). One of these species was e.g. Stenactis апnиа, which was recorded in all of the classes of the ruderal vegetation and also in all of the classes of the forest vegetation. In the ruderal vegetation, this species was recorded in both periods. In the forest vegetation, it was recorded only in the more recent period (Table 1). According to the investigation of a potential contamination by invasive plants, resulting from the trade exchange between Slovakia and Romania (Ferus et al., 2015), Stenactis annua belong among the 30 worst invasive plant taxa, which were mostly exported from Romania to Slovakia in 2006-2010. This fact could increase the proportion of this species in the vegetation of Bratislava in the more recent period.

The spectrum of the recorded invasive species in the various classes of the vegetation is different. It is not surprising that in the classes of ruderal vegetation formed by therophytes (Polygono-Poetea annuae and Sisymbrietea), more therophyte invasive plants are represented (e.g. Ambrosia artemisiifolia, Atriplex tatarica, Conyza canadensis, Echinochloa crus-galli, Matricaria discoidea) (Table 1). In the classes of ruderal vegetation formed by hemicryptophytes (Artemisietea vulgaris and Epilobietea angustifolii) more hemicryptophyte invasive taxa can be found (e.g. Aster novi-belgii agg., Cardaria draba, Rumex patientia, Solidago canadensis, S. gigantea) (Table 1).

The taxa Aster novi-belgii agg., Solidago canadensis, and S. gigantea frequently occur also in the forest types of vegetation, mainly in the more recent period (Table 1). In the ruderal types of vegetation, mainly the juvenile forms of the phanerophyte invasive plants are present. In the forest vegetation, also grown up shrubs and trees occur, mainly the species Ailanthus altissima, Lycium barbarum, Negundo aceroides, and Robinia pseudoacacia. One of the widespread invasive species in all of the forests types of vegetation is also the species Impatiens parviflora (Table 1). The invasion of the neophytes Ailanthus altissima, Aster novi-belgii agg., Impatiens parviflora, Negundo aceroides, Robinia pseudoacacia, Solidago canadensis, and S. gigantea in the remnants of the Bratislava's forests have been recently reported also by the other authors (Feráková \& Jarolímek, 2011). Invasive species Impatiens parviflora, Robinia pseudoacacia, and Solidago gigantea belong to the most 
frequently occurring neophytes also in the hardwood floodplain forests in the whole Pannonian biogeographic region (Petrášová et al., 2013).

According to the findings of some authors (Chmura \& Sierka, 2006), Impatiens parviflora is not a competitor for native species in some of the types of the forest vegetation, and therefore it has no negative impact on their diversity. However, in some types of the forest vegetation, e.g. in the hardwood floodplain forest (class Alno glutinosae-Populetea albae), the cover of the invasive species Impatiens parviflora was negatively correlated with native species richness (Chmura \& Sierka, 2006). Another study (Sitzia, Campagnaro, Dainese, \& Cierjacks, 2012) shows that the plant communities, where the other widespread invasive species - Robinia pseudoacacia formes the tree layer, have significantly lower b-diversity values in comparison to stands formed by the native species.

The negative impact of alien invasive plants on the floodplain forest vegetation can be indirectly supported by the results of our analysis, because in the classes of floodplain forest vegetation, where the increase in the proportion of the invasive species over the time was recorded (Figure 2), the decrease of the Shannon-Wiener index of the diversity has been found (Figure 4).

The increase of invasive species could play a role also in an overall decrease of species diversity in the types of ruderal vegetation, e.g. in the classes Artemisietea vulgaris and Epilobietea angustifolii, where the significant increase of the invasive species proportion (Figure 1) and the decrease of the diversity index (Figure 3) have been recorded. The explanation could be the fact that many of the plant communities of these classes, which were recorded in the more recent period were formed monodominantly by invasive taxa (mainly taxa such as Aster novi-belgii agg., Fallopia japonica, Helianthus tuberosus, Solidago canadensis, and S. gigantea, (Rendeková, 2016a) and thus had a very low diversity.

The lower biodiversity could already be a consequence of a high proportion of the invasive taxa (Manchester \& Bullock, 2000; Stohlgren et al., 2011). Vice versa, from one scientific point of view, the communities with lower biodiversity are less stable and therefore less resistant to invasions by alien species (Case, 1990; Tilman, 1997). Therefore, we admit that the increase in the percentual number of the invasive species in some classes (Figures 1 and 2) could be the consequence of the decrease of the diversity (Figures 3 and 4), as the high proportion of the invasive species could be consequence of the vulnerable plant community with poor biodiversity (Case, 1990; Tilman, 1997). Our study indirectly support this theory also because in the dry grassland vegetation of the class Festuco-Brometea with the highest values of the Shannon-Wiener diversity index (Figures 3 and 4), no invasive taxa were recorded in both periods (Figure 2, Table 1).

In the class Festuco-Brometea, only a slight decrease of the diversity index over the time was recorded (Figure 4), and this decrease is most likely connected mainly to the abandonment of the traditional management on the habitats, where these plant communities grow, not with the direct negative impact of the invasive species. However, it is the fact that the crucial part of the management for the conservation of the dry grasslands of Devínska Kobyla National Nature Reserve is the removing of the alien invasive woody species (e.g. Robinia pseudoacacia) (Hegedüšová \& Senko, 2011). The similar trend in the species diversity dynamics, just as we recorded, have also been observed by other authors (Hegedüšová \& Senko, 2011), who recorded the decrease of the overall species diversity and the decrease of the cover of endangered Red List species in dry grassland vegetation of the Poo badensis-Festucetum pallentis plant community in Devínska Kobyla over the time.

The decrease of the overall species diversity over the time has also been recorded in the urban flora and vegetation in some European cities (Pyšek et al., 2004) and the decrease of the species richness of native taxa in the ruderal and forest vegetation can be connected with the increase in the proportion of invasive alien neophytes (Chocholoušková \& Pyšek, 2003; Lososová \& Simonová, 2008; Petrášová et al., 2013). In the urban habitats in many European cities, the increase of the proportion of neophyte alien plant taxa over the time have been observed (Pyšek \& Mandák, 1997; Chocholoušková \& Pyšek, 2003; Lososová \& Simonová, 2008; Gregor et al., 2012; Rendeková \& Mičieta; 2017). Over time, a significant increase in the proportion of neophytes was also recorded in the hardwood floodplain forests in the Pannonian Region (Petrášová et al., 2013) and many other habitats in Slovakia (Medvecká et al., 2014). All of these studies confirm the same trend as our study because the majority of the invasive taxa we recorded are neophytes (Table 1) and their proportion increased over the time in the majority of the analyzed types of vegetation (Figures 1 and 2).

Our results agree with the findings of above-mentioned authors, and also with the finding of some other authors (McKinney \& Lockwood, 1999; Olden, LeRoy Poff, M. R. Douglas, M. E. Douglas, \& Fausch, 2004), which indicate the process of homogenization of the biota at a larger scale. According to these authors, many species 
are declining and are being replaced by a much smaller number of expanding species, mainly alien species, and this whole process results in a more homogeneous biosphere with lower diversity.

These trends in the species composition and diversity dynamics might be caused by various factors. In the case of the ruderal vegetation, it might be the increase in the transport of goods and passengers or the boom in the construction activity, both resulting in higher propagule pressure of invasive species in Bratislava city during the last decades. One of the factors might also be the change in the gardening methods because in recent years, the citizens prefer the invasive ornamental plant growing (e.g. Aster novi-belgii agg., Fallopia japonica, Helianthus tuberosus, Solidago gigantea) in gardens. In case of floodplain forests, the change in the forest management could have contributed to an incrasing proportion of invasive species, because some of the invasive neophyte tree species were preferred (e.g. Robinia pseudoacacia).

Our study demonstrates that human-caused changes in the city environment can resulted in an increasing proportion of alien invasive species in vegetation over the time. One of the consequences of invasions of alien species is the biodiversity loss. The extinctions, for which invasive taxa are responsible, cause the global diversity to be reduced much faster than it is recovered (Stohlgren et al., 2011).

\section{Conclusion}

Our study showed remarkable changes in the species composition and diversity of the various types of vegetation over the time in the Bratislava city. The statistical analysis revealed the significant increase of the average percentual number of invasive alien species in the majority of classes of forest and ruderal vegetation over the time. In both time periods, the ruderal vegetation accommodated the highest percentual number of invasive species among the analyzed vegetation types, and the floodplain forests were the second most invaded ones. In the dry grasslands from the class Festuco-Brometea, no invasive species were recorded in both periods. In total, 26 invasive alien taxa were recorded in the vegetation of Bratislava. Five invasive species (Echinocystis lobata, Fallopia japonica, Helianthus tuberosus, Juncus tenuis, and Solidago canadensis) were recorded only in the more recent period.

The analysis also revealed that in the majority of vegetation classes, where the proportion of invasive species increased, the Shannon-Wiener index of diversity of all species decreases with time. In the dry grassland vegetation from the class Festuco-Brometea, which contains no invasive species at all, the Shannon-Wiener index of diversity reaches the highest values among all of the analyzed types of vegetation of Bratislava city.

The increase of the invasive species and resultant decrease in the overall biodiversity may be connected with human-caused changes in the habitats of Bratisava city during the last decades. Results of our study provide a helpful tool to evaluate the effect of human activities on the biodiversity of vegetation and invasive species dynamics in cities. This results can be useful and helpful in solving environmental protection issues.

\section{Acknowledgements}

This research was supported by the Grant Agency VEGA (Bratislava), Grant 1/0885/16. We also sincerely thank dr. Jarolímek for providing us his phytosociological data, Mr. Aaron Fishbone for English grammar proofreading of the manuscript and doc. MUDr. Viera Rendeková, CSc. for supporting our research.

\section{References}

Aronson, M. F. J., Handel, S. N., La Puma, I. P., \& Clemants, S. E. (2015). Urbanization promotes non-native woody species and diverse plant assemblages in the New York metropolitan region. Urban Ecosystems, 18(1), 31-45. https://doi.org/10.1007/s11252-014-0382-z

Barkman, J. J., Doin, H., \& Segal, S. (1964). Kritische Bemerkungen und Vorschläge zur quantitativen Vegetationsanalyse. Acta Botanica Neerlandica, 13(3), 394-419. https://doi.org/10.1007/978-3-7091 $-8110-2$

Bobbink, R., During, H. J., Schreurs, J., Willems, J., \& Zielman, R. (1987). Effects of selective clipping and mowing time on species diversity in chalk grassland. Folia Geobotanica et Phytotaxonomica, 22(4), 363-376. https://doi.org/10.1007/BF02853233

Bomanowska, A., Rewicz, A., Wolski, G. J., \& Katarzyna, K. (2017). Invasive alien pants in protected areas within city borders, Lódź (Poland). Pakistan Journal of Botany, 49(1), 311-316.

Braun-Blanquet, J. (1964). Pflanzensoziologie, Grundzüge der Vegetationskunde (3rd ed.). Wien: Springer-Verlag. https://doi.org/10.1111/j.1438-8677.1964.tb00164.x 
Case, T. J. (1990). Invasion resistance arises in strongly interacting species-rich model competition communities. Proceedings of the National Academy of Sciences of USA, 87(24), 9610-9614. https://doi.org/10. 1073/pnas.87.24.9610

Catford J. A., Daehler C. C., Murphy H. T., Sheppard A. W., Hardesty B. D., Westcott D. A., ... Hulme P. E. (2011). The intermediate disturbance hypothesis and plant invasions: implications for species richness and management. Perspectives in Plant Ecology, Evolution and Systematics, 14(3), 231-241. https://doi.org/10. 1016/j.ppees.2011.12.002

Chmura, D., \& Sierka, E (2006). Relation between invasive plant and species richness of forest floor vegetation: a study of Impatiens parviflora DC.. Polish Journal of Ecology, 54(3), 417-428.

Chocholoušková, Z., \& Pyšek, P. (2003). Changes in composition and structure of urban flora over 120 years: a case study of the city of Plzeň. Flora, 198, 366-376. https://doi.org/10.1078/0367-2530-00109

Chytrý, M., Pyšek, P., Tichý, L., Knollová, I., \& Danihelka, J. (2005). Invasions by alien plants in the Czech Republic: a quantitative assessment across habitats. Preslia, 77, 339-354.

Chytrý, M., Jarošík, V., Pyšek, P., Hájek, O., Knollová, I., Tichý, L., \& Danihelka, J. (2008). Separating habitat invasibility by alien plants from the actual level of invasion. Ecology, 89(6), 1541-1553. https://doi.org/10. 1890/07-0682.1

Feráková, V., \& Kocianová, E. (Eds.). (1997). Flóra, geológia a paleontológia Devínskej Kobyly [Flora, geology and paleontology of the Devinska Kobyla Mt.]. Bratislava: Litera.

Feráková, V., \& Jarolímek, I. (2011). Bratislava. In J. K. Kelcey, \& N. Müller (Eds.), Plants and habitats of European cities (pp. 79-129). New York: Springer. https://doi.org/10.1007/978-0-387-89684-7_4

Ferus, P., Sîrbu, C., Eliáš, P. jun., Konôpková, J., Ďurišová, L', Samuil, C., \& Oprea, A. (2015). Reciprocal contamination by invasive plants: analysis of trade exchange between Slovakia and Romania. Biologia, 70(7), 893-904. https://doi.org/10.1515/biolog-2015-0102

Filep, R., Pal, R. W., Balázs, V. L., Mayer, M., Nagy, D. U., Cook, B. J., \& Farkas, Á. (2016). Can seasonal dynamics of allelochemicals play a role in plant invasions? A case study with Helianthus tuberosus L.. Plant Ecology, 217(12), 1489-1501. https://doi.org/10.1007/s11258-016-0662-1

Gastauer, M., Messias, M. C. T. B., \& Neto, J. A. A. M. (2012). Floristic composition, species richness and diversity of Campo Rupestre Vegetation from the Itacolomi State Park, Minas Gerais, Brazil. Environment and Natural Resources Research, 2(3), 115-130. http://dx.doi.org/10.5539/enrr.v2n3p115

Gregor, T., Bönsel, D., Starke-Ottich, I., \& Zizka, G. (2012). Drivers of floristic change in large cities - A case study of Frankfurt/Main (Germany). Landscape and Urban Planning, 104, 230-237. https://doi.org/10. 1016/j.landurbplan.2011.10.015

Hajdúk, J. (1986). Results of vegetation changes research on permanent trial plots and their importance for the management of the State Nature Reserve Devínska Kobyla. Ochrana prírody, 7, 79-105.

Hegedüšová, K. (2007). Central database of phytosociological samples (CDF) in Slovakia. Bulletin Slovenskej botanickej spoločnosti, 29, 124-129.

Hegedüšová, K., \& Senko, D. (2011). Successional changes of dry grasslands in southwestern Slovakia after 46 years of abandonment. Plant Biosystems, 145(3), 666-687. http://dx.doi.org/10.1080/11263504.2011. 601605

Hennekens, S. M., \& Schaminée, J. H. J. (2001). TURBOVEG, a comprehensive data base management system for vegetation data. Journal of Vegetation Science, 12(4), 589-591. https://doi.org/10.2307/3237010

Hill, M. O. (1973). Diversity and evenness: a unifying notation and its consequences. Ecology, 54, 427-432. https://doi.org/10.2307/1934352

Hill, T., \& Lewicki, P. (2007). STATISTICS: Methods and Applications. Tulsa, OK: StatSoft.

Hobbs, R. J., \& Huenneke, L. F. (1992). Disturbance, diversity, and invasion: implications for conservation. Conservation Biology, 6(3), 324-337. https://doi.org/10.1046/j.1523-1739.1992.06030324.x

Jarolímek, I. (1983). Ruderálne spoločenstvá Bratislavy [Ruderal communities of Bratislava] (Unpublished doctoral dissertation). Institute of Botany SAS, Bratislava, Slovakia. 
Kaleta, M. (1965). Vegetačné pomery Devínskej Kobyly. [Vegetation of Devínska Kobyla Mt.] (Unpublished master's thesis). Comenius University in Bratislava, Slovakia (Faculty of Natural Sciences, Department of Botany).

Lonsdale, W. M. (1999). Global patterns of plant invasions and the concept of invasibility. Ecology, 80, 1522-1536. https://doi.org/10.1890/0012-9658(1999)080\%5B1522:GPOPIA\%5D2.0.CO;2

Lososová, Z., \& Simonová, D. (2008). Changes during the 20th century in species composition of synanthropic vegetation in Moravia (Cezch Republic). Preslia, 80, 291-305.

Lososová, Z., Chytrý, M., Danihelka, J., Tichý, L., \& Ricotta, C. (2016). Biotic homogenization of urban floras by alien species: the role of species turnover and richness differences. Journal of Vegetation Science, 27, 452-459.

Mack, R. N., Simberloff, D., Lonsdale,W. M., Evans, H., Clout, M., \& Bazzaz, F. A. (2000). Biotic invasions: causes, epidemiology, global consequences, and control. Ecological Applications, 10(3), 689-710. https://doi.org/10.1890/1051-0761(2000)010[0689:BICEGC]2.0.CO;2

Manchester, S. J., \& Bullock, J. M. (2000). The impacts of non-native species on UK biodiversity and the effectiveness of control. Journal of Applied Ecology, 37(5), 845-864. https://doi.org/10.1046/j.1365 $-2664.2000 .00538 . \mathrm{x}$

Marhold, K. (1998). Ferns and flowering plants. In K. Marhold, \& F. Hindák (Eds.), Checklist of non-vascular and vascular plants of Slovakia (pp. 333-687). Bratislava: Veda.

McKinney, M. L., \& Lockwood, J. (1999). Biotic homogenization: a few winners replacing many losers in the next mass extinction. Trends in Ecology \& Evolution, 14, 450-453. https://doi.org/10.1016/S0169-5347 (99)01679-1

Medvecká, J., Jarolímek, I., \& Zaliberová, M. (2009). Dynamics and distribution of neophytes in the Horná Orava Region (North Slovakia). Hacquetia, 8(2), 147-158. https://doi.org/10.2478/v10028-009-0009-8

Medvecká, J., Kliment, J., Májeková, J., Halada, L., Zaliberová, M., Gojdičová, E., ... Jarolímek, I. (2012). Inventory of alien species of Slovakia. Preslia, 84, 257-309.

Medvecká, J., Jarolímek, I., Senko, D., \& Svitok, M. (2014). Fifty years of plant invasions dynamics in Slovakia along a 2,500 m altitudinal gradient. Biological Invasions, 16(8), 1627-1638. https://doi.org/10.1007/ s10530-013-0596-7

Miškovic, J., \& Dúbravcová, Z. (2003). Zmeny v lesných spoločenstvách na Devínskej Kobyle (JZ Slovensko). [Changes of forest communities in Devínska Kobyla (SW Slovakia)]. Bulletin Slovenskej botanickej spoločnosti, 25, 157-168.

Miškovic, J., \& Dúbravcová, Z. (2004). Zmeny v spoločenstve Ranunculo illyrici-Festucetum valesiacae Klika 1931 na Devínskej Kobyle po 36 rokoch. [Changes of the Ranunculo illyrici-Festucetum valesiacae Klika 1931 plant community in the locality of Devínska Kobyla Hill (SW Slovakia) after the last 36 years]. Bulletin Slovenskej botanickej spoločnosti, 26, 185-192.

Mucina, L., Bültmann, H., Dierßen, K., Theurillat, J. P., Raus, T., Čarni, A., ... Tichý, L. (2016). Vegetation of Europe: hierarchical floristic classification system of vascular plant, bryophyte, lichen, and algal communities. Applied Vegetation Science, 19(S1), 3-264. https://doi.org/10.1111/avsc.12257

Olden, J. D., LeRoy Poff, N., Douglas, M. R., Douglas, M. E., \& Fausch, K. D. (2004). Ecological and evolutionary consequences of biotic homogenization. Trends in Ecology \& Evolution, 19(1), 18-24. https://doi.org/10.1016/j.tree.2003.09.010

Petrášová, M., Jarolímek, I., \& Medvecká, J. (2013). Neophytes in Pannonian hardwood floodplain forests history, present situation and trends. Forest Ecology and Management, 308, 31-39. https://doi.org/10. 1016/j.foreco.2013.07.041

Pimentel, D., McNair, S., Janečka, J., Wightman, J., Simmonds, C., O'Connell, C., ... Tsomondo, T. (2001). Economic and environmental threats of alien plant, animal, and microbe invasions. Agriculture, Ecosystems \& Environment, 84(1), 1-20. https://doi.org/10.1016/S0167-8809(00)00178-X

Podani, J. (2001). SYN-TAX 2000, Computer program for data analysis in ecology and systematics for Windows 95, 98 \& NT, User's manual. Budapest: Scientia Publishing. 
Pyšek, P., \& Mandák, B. (1997). Fifteen years of changes in the representation of alien species in Czech village flora. In J. H. Brock, M. Wade, P. Pyšek, \& D. Green (Eds.), Plant invasions: studies from North America and Europe (pp. 183-190). Leiden: Backhuys Publishers.

Pyšek, P., \& Tichý, L. (2001). Rostlinné invaze. Brno: Rezekvítek.

Pyšek, P., Chocholoušková, Z., Pyšek, A., Jarošík, V., Chytrý, M., \& Tichý, L. (2004). Trends in species diversity and composition of urban vegetation over three decades. Journal of Vegetation Science, 15, 781-788. https://doi.org/10.1111/j.1654-1103.2004.tb02321.x

Pyšek, P., Bacher, S., Chytrý, M., Jarošík, V., Wild, J., Celesti-Grapow, L., ... Hulme, P.E. (2010). Contrasting patterns in the invasions of European errestrial and freshwater habitats by alien plants, insects and vertebrates. Global Ecology and Biogeography, 19(3), 317-331. https://doi.org/10.1111/j.1466 $-8238.2009 .00514 . \mathrm{x}$

Pyšek, P., \& Richardson, D. M. (2010). Invasive species, environmental change and management, and health. Annual Review of Environment and Resources, 35, 25-55. https://doi.org/10.1146/annurev-environ-033009 $-095548$

Rendeková, A., Kerekeš, E., \& Miškovic, J. (2014). Rare and interesting ruderal plant communities of Bratislava. Acta Botanica Universitatis Comenianae, 49, 13-18.

Rendeková, A. (2016a). Dynamika synantropnej flóry a vegetácie v mestských aglomeráciách [Dynamics of the synanthropic flora and vegetation in urban agglomerations] (Unpublished writing to doctoral dissertation). Comenius University in Bratislava, Slovakia (Faculty of Natural Sciences, Department of Botany).

Rendeková, A. (2016b). Little-known ruderal plant communities recorded in Bratislava. Acta Botanica Universitatis Comenianae, 51, 23-29.

Rendeková, A., \& Mičieta, K. (2017). Changes in the representation of alien taxa in ruderal vegetation of an urban ecosystem over 50 years. A case study from Malacky city, Slovakia, Central Europe. Urban Ecosystems, 20(4), 867-875. https://doi.org/10.1007/s11252-016-0638-X

Richardson, D. M., Pyšek, P., Rejmánek, M., Barbour, M. G., Panetta, F. D., \& West, C. J. (2000). Naturalization and invasion of alien plants: concepts and definitions. Diversity and Distributions, 6(2), 93-107. https://doi.org/10.1046/j.1472-4642.2000.00083.x

Richardson, D. M., Holmes, P. M., Esler, K. J., Galatowitsch, S. M., Stromberg, J. G., Kirkman, S. P., ... Hobbs, R. J. (2007). Riparian vegetation: degradation, alien plant invasions, and restoration prospects. Diversity and Distributions, 13, 126-139. https://doi.org/10.1111/j.1366-9516.2006.00314.x

Senko, D., \& Miškovic, J. (2006). Návrh na manažment biotopov vybraných taxónov z rodu Ophrys L. (Orchidaceae) na Devínskej Kobyle (Bratislava) [Proposed management for the biotopes with selected taxons of Ophrys L. (Orchidaceae) at the Devínska Kobyla Mt. (Bratislava)]. Miscellanea Geographica, 12, 47-61.

Simonová, D., \& Lososová, Z. (2008). Which factors determine plant invasions in man-made habitats in the Czech Republic?. Perspectives in Plant Ecology, Evolution and Systematics, 10(2), 89-100. https://doi.org/10.1016/j.ppees.2007.11.003

Sitzia, T., Campagnaro, T., Dainese, M., \& Cierjacks, A. (2012). Plant species diversity in alien black locust stands: a paired comparison with native stands across a north-Mediterranean range expansion. Forest Ecology and Management, 285, 85-91. http://dx.doi.org/10.1016/j.foreco.2012.08.016

Stohlgren, T. J., Pyšek, P., Kartesz, J., Nishino, M., Pauchard, A.,Winter, M., ... Font, X. (2011). Widespread plant species: natives versus aliens in our changing world. Biological Invasions, 13(9), 1931-1944. https://doi.org/10.1007/s10530-011-0024-9

Šibík, J. (2012). Slovak vegetation database. In J. Dengler, J. Oldeland, F. Jansen, M. Chytrý, J. Ewald, M. Finckh, ... J. H. J. Schaminée (Eds.), Vegetation databases for the 21st century (pp. 429-429). Biodiversity \& Ecology, 4(1). https://doi.org/10.7809/b-e.00216

Tichý, L. (2002). JUICE, software for vegetation classification. Journal of Vegetation Science, 13, 451-453. https://doi.org/10.1111/j.1654-1103.2002.tb02069.x

Tilman, D. (1997). Community invasibility, recruitment limitation, and grassland biodiversity. Ecology, 78(1), 81-92. https://doi.org/10.1890/0012-9658(1997)078\%5B0081:CIRLAG\%5D2.0.CO;2 
Vilá, M., Pino, J., \& Font, X. (2007). Regional assessment of plant invasions across different habitat types. Journal of Vegetation Science, 18(1), 35-42. https://doi.org/10.1111/j.1654-1103.2007.tb02513.x

Walter, J., Ess, F., Englisch, T., \& Kiehn, M. (2005). Neophytes in Austria: Habitat preferences and ecological effects. In W. Nentwig, S. Bacher, M. Cock, H. J. Dietz, A. Gigon, \& R. Wittenberg (Eds.), Biological invasions - From ecology to control (pp. 13-25). Berlin: Neobiota 6.

Willems, J. H. (1983). Species composition and above-ground phytomass in chalk grassland with different management. Vegetatio, 52(3), 171-180. https://doi.org/10.1007/BF00044994

Young, H. S., Parker, I. M., Gilbert, G. S., Guerra, A. S., \& Nunn, C. L. (2017). Introduced species, disease ecology, and biodiversity-disease relationships. Trends in Ecology \& Evolution, 32(1), 41-54. https://doi.org/10.1016/j.tree.2016.09.008

Zajac, A., Tokarska-Guzik, B., \& Zajac, M. (2011). The role of rivers and streams in the migration of alien plants into the Polish Carpathians. Biodiversity Research and Conservation, 23, 43-56. https://doi.org/10. 2478/v10119-011-0012-Z

Zisenis, M. (2015). Alien plant species: a real fear for urban ecosystems in Europe?. Urban Ecosystems, 18(2), 355-370. https://doi.org/10.1007/s11252-014-0400-1

Žabka, M., Ďurišová, L., \& Eliáš, P. jun. (2015). Spreading of alien species in disturbed area: a case study from Opatovce nad Nitrou (SW Slovakia). Thaiszia - Journal of Botany, 25(2), 143-151.

\section{Copyrights}

Copyright for this article is retained by the author(s), with first publication rights granted to the journal.

This is an open-access article distributed under the terms and conditions of the Creative Commons Attribution license (http://creativecommons.org/licenses/by/4.0/). 